4

\title{
Farm Women and the Empowerment Potential in Value-Added Agriculture
}

\author{
Wynne Wright* and Alexis Annes** \\ * Associate Professor \\ Depts. of Community Sustainability and Sociology \\ 330 B Natural Resources Building \\ Michigan State University \\ East Lansing, MI 48824, USA \\ Tel: (517) 884-1372 \\ Email: wrightwy@anr.msu.edu \\ **Enseignant Chercheur \\ UMR LISST-Dynamiques Rurales_Ecole d'Ingénieurs de Purpan \\ 75 voie du TOEC \\ BP 57611 \\ 31076 Toulouse Cedex 3, France \\ Tel: (33) 561153086 \\ Email: alexis.annes@purpan.fr
}

\begin{abstract}
:
While the number of women in the U.S. is growing, less clear is whether increasing participation in agriculture translates into empowerment opportunities. Are invisibility and disempowerment lingering expressions of farm women's experience? Using qualitative data drawn from 32 interviews with Michigan value-added farmers, we examine the extent to which women have been able to experience empowerment, and the ways in which value-added agriculture specifically fosters an empowering context. We adopt a conceptualization of empowerment from the development scholarship in order to establish a baseline for scrutiny, viewing empowerment as a multi-dimensional process constituting the 'power to' realize one's goals, the opportunity to exercise 'power with' others, and the ability to find and nurture 'power within' the self. Our findings indicate that value-added agriculture provides a unique context for women's empowerment. At the same time, the extent to which value added-agriculture constitutes a venue for women's empowerment is complex, multifaceted, and requires constant negotiation. It can be organized and performed in such a way as to subvert the empowerment process by confining women to specific social locations that may reify oppressive structures.
\end{abstract}




\section{Introduction}

Recent census data reveal a growing representation of women in agriculture. In 2012,

3 U.S. women farmers reached 969,672 or 30 percent of the farming population, an increase of 14

4 percent over the past decade (2002-2013) (Census of Agriculture 2012; 2002). Some journalists

5 have summarized this trend as "breaking the "grass ceiling"' (Doering 2013) whereby invisible

6 barriers have been removed and opportunities to production agriculture are no longer denied to

7 women. In this paper, we redirect an analytical lens on farm women to test extant theoretical

8 understandings of gender relations in agriculture, as well as to gauge the extent to which the, so-

9 called, "breaking of the 'grass' ceiling'" is indeed an accurate portrayal of women's experience

10 or merely enthusiastic reporter rhetoric.

11 The now classical feminist literature on gender relations in agriculture in the Global

12 North in general, and in the United States in particular, has focused on the family farm unit

13 (Preibisch and Grez 2010) and hinges on a fundamental conclusion that women have made

14 significant contributions to family farm economic and social well-being through their on and off-

15 farm contributions (Brandth 1995; Fink 1992; Leckie 1996; Neth 1995; Pearson 1979; Rosenfeld

16 1985; Sachs 1983), yet their efforts frequently go unrecognized or diminished. This results in the

17 disempowerment of women by deflating their social status, curtailing their access to material

18 resources, denigrating their identities (Gasson 1980; Jellison 1993; Little 2002), as well as

19 portraying "a very biased view of agricultural history" (Alston 2003). Sachs and Alston

20 (2010:278) argue that "undoing existing gender arrangements in agriculture requires the

21 reshuffling of power relations and the reframing of discourses surrounding gender." The

22 demographic up-tick among American farm women presents an opportunity to reinvigorate this 
conversation and explore the extent to which invisibility and disempowerment are lingering expressions of farm women's experience in late capitalism.

A recent body of research posits that this new generation of women farmers are more likely to be found on operations which add value to agriculture (Bock 2004; McNally 2001; Trauger 2004). For example, 40 percent of community-supported agriculture farms are operated by women (Jarosz 2011) and women are more likely to engage in farm tourism (Brandth and Haugen 2011; Garcia-Ramon, Canoves, and Valdovinos 1995) - both variants of value-added agriculture. In this paper, our goal is to examine the context of participation in value-added agriculture to ask how women farmers experience opportunities for and impediments to empowerment. More specifically, this study examines the forces that empower women to engage in farming generally, and value-added agriculture specifically. We also consider the ways in which value-added agriculture creates the context for nurturing women's empowerment. Why focus on value-added agriculture? First, much of the work of value-added agriculture is performed in a public setting, creating distinctive opportunities for visibility. Many women are taking their farm on the road via face-to-face sales at farmer's markets, communitysupported agriculture, or becoming farm spokespersons via agritourism. Secondly, there appears to be a lack of scholarship on the explicit intersection of value-added agriculture and gender. Research on the topic has more overtly taken up the question of women's empowerment vis-ávis either conventional or sustainable farming systems, but few have explored value-added agriculture. Existing studies have found that women's participation in farm decision-making has led to empowerment, yet, as noted above, much of the literature contends that such participation has occurred less in conventional than in sustainable farming systems (DeLind and Ferguson 1999; Hassanein 1999; Leipins 1998; Meares 1997; Wells 1998). Like agritourism (Brandth and 
1 Haugen 2011), many practices associated with value-added agriculture accentuate skills often

2 performed within traditional notions of gendered-work (cooking, cleaning, caring) suggesting the

3 need for investigation of the empowerment potential in value-added agriculture.

$4 \quad$ Relatedly, not only is value-added agriculture explicitly missing from the empowerment

5 debate, but the use of conventional/sustainable binaries can mask heterogeneity within the

6 typical farm operation, eclipsing the spaces where women often work. The structure of much of

7 U.S. agriculture is such that conventional or sustainable farming systems are not always

8 analytically discrete. Attributes typically assigned to conventional farms, such as large scale

9 farms that continuously grow single crops over many seasons and produce a high-yielding

10 uniform commodity with the use of pesticides and fertilizers and that rely upon technological

11 innovation and large capital investments, may be found in farms that practice value-added

12 agriculture. Yet, value-added agriculture is typically treated as an instance of sustainable

13 farming, in part because of its ability to stimulate economic diversity on the farm, create

14 employment opportunities, and revitalize rural development - all functions frequently aligned

15 with sustainable agriculture. Examples of this hybrid model can be seen in fruit and small

16 vegetable producers, such as apple or blueberry growers who produce by 'conventional'

17 methods, yet process and market according to 'value-added' practices by processing apples into

18 cider or pies, or marketing direct to the consumer.

19 Such variations are supported by previous scholarship which has found that simplistic binaries

20 do not map strictly onto perceived production practices and, in doing so, masks complexity in

21 understanding agricultural change and attendant management approaches (Fairweather et al.

22 2009; Lockie and Halpin 2005; Rosin and Campbell 2008). For example, Hall and Mogyorody

23 (2007:295) found that organic agriculture did not create any unique conditions for gender 
1 empowerment in Ontario, rather "most organic farms exhibited a fairly conventional gendered

2 division of labor and power." For these reasons, neither conventional nor sustainable farming

3 systems are discrete, thus we focus on the much narrower system of value-added agriculture

4 which can serve as a more accurate benchmark to explore empowerment.

In examining the extent to which women have been able to create a space for

6 empowerment free from the constraints of social structures, such as patriarchy, heterosexism and

7 agrarian ideology, we look to the development literature to conceptualize empowerment as a

8 multi-dimensional process constituting the "power to" improve one's conditions, the opportunity

9 to exercise "power with" others, and the ability to find and nurture "power within" the self

10 (Charlier 2006; Oxaal and Baden 1997). Drawing upon interview data with 32 Michigan farm

11 women engaged in value-added agriculture, we examine the extent to which they express these

12 various forms of power.

This study allows us to add to the literature on gender and value-added agriculture in

14 general, and value-added agriculture as a vehicle for women's empowerment, in particular. This

15 work also contributes to the conceptualization of empowerment - a concept which when applied

16 to rural women, has disproportionately focused on the experiences of women in the Global

17 South. By turning our geographic lens on American women, we are able to augment our

18 understanding of this process and systematically distinguish the experience of farm women's

19 empowerment by place.

20

\section{Conceptualizing Empowerment}

Feminist scholars have made formidable inroads in understanding the intersection

23 between gender and power relations in agriculture. Within the field of sociology of agrifood 
1 systems, the debates about the role of women in agriculture and their power/powerlessness are

2 often framed in terms of conventional or sustainable/alternative agriculture farming systems.

3 Early scholarship found conventional farming systems to be organized economically, politically,

4 and socio-culturally exclusively, marginalizing women from land ownership (Jensen 1991) and

5 active roles in production and decision-making (Neth 1995; Rosenfeld 1985; Sachs 1983;

6 Whatmore 1991). Conventional agriculture was undergirded by input systems that, likewise,

7 displaced women by alienating them from technology (Jellison 1993) and knowledge acquisition

8 (Hassanein 1999; Kiernan et al. 2012). The growth in alternative or sustainable agriculture has

9 opened opportunities for women, to not only resist the hegemony of conventional farming

10 systems, but to engage in agriculture via avenues historically denied to them. A growing body of

11 scholarship has credited this sea change with empowering women traditionally excluded from

12 this sector of the economy (DeLind and Ferguson 1999; Trauger 2004; Wells 1998).

13 A common denominator running through this literature on U.S. farm women and

14 empowerment draws attention to the role of collective action and networks for empowering

15 women in agriculture. For Wells (1998), it was the organizing of Iowa farm women in the

16 Women, Food and Agriculture Network which stimulated opportunities for empowerment via

17 collective action. Delind and Ferguson (1999:198) found that community-supported agriculture

18 likewise, served as a "feminine form of empowerment" as it embodied "both a social and

19 physical space within which relationships of everyday life, practical gender concerns that relate

20 to women's life positions and experiences, can be variously expressed." Trauger (2004:290) sees

21 sustainable agriculture as "new spaces of empowerment and resistance" where women and

22 agriculture work are made visible and valued. This insight leads her to conclude that "perhaps

23 changing the spatial institutions of work may have more to do with liberating women from 
oppressive gender relations and simply changing the kind of work they do" (2004:304). We offer this literature as a historical anchor, aware that the present research is distinct from these studies in its focus on value-added agriculture, and, therefore, limits any comparative function.

Empowerment may appear like a simple concept to define, yet, as Malhotra, Schuler, and Boender (2002:22) write, "there is a tendency to use the term loosely, without embedding it in a larger conceptual framework." Rowlands (1995) argues that the concept of empowerment has muddled scholarly thinking and practice because understanding of the root concept - power - is disputed. Development scholars tend to view empowerment as both a process and an exercise in agency (Ali 2013; Malhotra and Schuler 2005). Nayaran (2005:4) defines empowerment as "the expansion of freedom of choice and action to shape one's life." For Kabeer (2001:41), empowerment is the "expansion in people's ability to make strategic life choices in a context where this ability was previously denied to them." Both definitions stress the importance of agency in charting one's future and they centralize the role of process, highlighting a temporal component, but neither say anything about the forms in which power may be realized.

Others draw upon Foucault (Charlier 2006; Oxaal and Baden 1997; Rowlands 1997; Williams, Seed, and Mwau 1994) to problematize the meaning of empowerment. These feminist development scholars have identified a multi-dimensional concept of power that consists of four distinct types: "power over," "power to," "power with," and "power within."

"Power over" implies relations of domination and/or subordination. This type of power rests upon the control and domination of one group over another whose consent to be dominated may be given freely or extracted illegitimately. Rowlands (1995:101) writes that "a gender analysis shows that 'power over' is wielded predominantly by men over other men, by men over 
1 women, and by dominant social, political, economic, or cultural groups over those who are

2 marginalized." Empowerment necessitates a reconsideration of patriarchy and relations of

3 domination between men and women and it also mandates that we scrutinize other patterns of

4 domination embedded in socio-cultural arrangements, such as racism, colonialism, and

5 heterosexism (Charlier 2006). Only once imbalances embedded in these relations are dismantled,

6 can we initiate a power shift (Kabeer 1999; 2001). Power and empowerment, then, are

7 inextricably intertwined. In this way, "power over" becomes the normative benchmark from

8 which all shifts in power can be assessed.

9 "Power to" chronicles the onset of change, or the process of empowerment. It includes

10 the ability to access resources, make decisions, exercise authority, and seek solutions. It

11 acknowledges the importance of skills and competencies (human resources) as well as material

12 resources (e.g., financial). Kelly argues that "power to" is "achieved by increasing one's ability

13 to resist and challenge "power over"' (quoted in Rowlands 1995:102).

14 Empowerment can also be approached as an individual or collective journey (Charlier

15 2006; Kabeer 2001; Umut Bespiran 2011). Underlying the notion of solidarity is "power with"

16 which signals the capacity to collectively organize in the pursuit of common goals. The

17 recognition that women can work together to achieve power in the form of collective action,

18 political structures, or other forms of social and economic cooperation alerts us to the fact that

19 there are dimensions beyond the "personal level", such as with "close relationships" in which

20 women cultivate empowerment (Rowlands 1995). An empowered group is one who understands

21 their "right to voice" and is vocal (Dahal 2013); it is a group which has acquired the power to

22 take charge of their lives (Kabeer 2001). 

refers to the development of self-esteem, including the ability of individuals to see themselves as confident agents of change and to cultivate a presentation of self that mirrors this internal image.

4 Others suggest that "power within" (aka "power inside") also refers to the practice of reflexivity, 5 or a form of consciousness-raising, whereby women develop the ability to identify the sources of 6 their oppression (Afshar 1998; Murthy et al. 2008).

To summarize, the notion of empowerment requires the ability to cultivate power,

8 exercise control over one's life, and the ability to make and implement choices (Charlier 2006;

9 Kabeer 2001; Sen 2000). In short, this ability is related to the acquisition to three of the four types of power: "power to," "power with,” and "power within" (Charlier 2006; Oxaal and Baden

11 1997; Rowlands 1995; Williams et al. 1994). For development scholars, empowerment is

12 transformative; women become agents of their own transformation. Empowerment is not an end13 state, however, but a dynamic, on-going process. Moreover, empowerment cannot be created by 14 others, it is inherently a personal process, yet conditions for empowerment can be constructed. 15 For Oxaal and Baden (1997), it is the context in which actions are undertaken which facilitate 16 this process. For this, we are especially intrigued to explore the context of value-added 17 agriculture as a vehicle for empowerment. After a brief discussion of the gendered transformations in U.S. agriculture and our research methods, we address the ways in which Michigan women articulate their experience of 20 empowerment via "power to," "power with," and "power within" value-added agriculture

21 systems as well as document lingering struggles to break free of the domination and 22 subordination that typify "power over." 


\section{Gendered Transformations in U.S. Agriculture}

Both the U.S. farm women and development scholarship views women's subordination to men as grounded, in part, in material and historical conditions (Charlier 2006; Fink 1992; Kabeer 1999; 2001; Sachs 1983). American farm women's lack of power has historically been accomplished by both legal and socio-cultural means and can be traced to the contours of a system of family farming as a household livelihood strategy. In the U.S. context, family farms have been defined first and foremost based on their dependence on the heterosexual couple as the primary unit of production (Allen and Sachs 2007; Fink 1992; Sachs 1983).

The post-World War II era ushered in an industrial mode of production "designed to increase productivity by substituting capital in the form of machinery, chemicals, and other purchased inputs and management inputs for labor and land" (Lyson 2004:18). Women were pushed out of the fields and either into the home or off the farm. Some found in off-farm employment the opportunity to make significant contributions to the household/farm unit. Others found a changing political and economic climate in the 1990s that gradually valorized localism, livelihood simplicity and sustainability, providing a new market opportunity to their 'unique' skills and subjectivities (DeLind and Ferguson 1999; Trauger 2001). Movement actors created markets where the production of smaller scale, lower-input, value-added agriculture and other non-market related goods, such as landscape and cultural amenities were highly sought after. As a result, many aspects of gendered farm work - once under-valued - have begun to take on increased importance, such as on-farm processing, direct sales, and farm tourism.

The work involved in value-added agriculture is often in keeping with socially constructed gendered skills, knowledge, and subjectivities, including women's reproductive work. For instance, hosting visitors on the farm is suggested by Brandth and Haugen (2010) to 
1 afford women the opportunity to use skills in the areas of caretaking, service, cooking, and

2 education. Cánoves et al. (2004) contend that although gendered skills undergird the nature of

3 such work, it may, nonetheless, allow women to move from a position of societal invisibility to

4 assume roles that hold promise for personal empowerment. Michigan is an excellent case in

5 which to study farm women's empowerment given the economic importance of value-added

6 agriculture which emerged from the state's agriculture and tourism sectors.

$7 \quad$ The food and agriculture sector is central to the economic portfolio of Michigan. It

8 generates $\$ 91.4$ billion in economic activity annually and employs 923,000 people or 22 percent

9 of the laborforce (Knudson and Peterson 2012). Surrounded by four of the five Great Lakes,

10 much of the state enjoys a unique micro-climate that is acutely suited to the production of fruits

11 and vegetables which are highly amenable to adding value at the farmgate. Secondly, this unique

12 geographical location has also enabled Michiganders to develop a vibrant tourism economy to

13 capitalize on markets created by travelers visiting the state for lakeside holidays. As a result,

14 value-added agriculture was established in Michigan long before many other areas of the U.S.

15 (Krauss 1999). Che, Veeck, and Veeck (2005:225) argue that "Michigan farmers are utilizing

16 agritourism as a value-added way to capitalize on their comparative advantages, their diverse

17 agricultural products, and their locations near large, urban, tourist-generating areas.”

18 Value-added agriculture is generally referred to as the process of differentiating the raw

19 agriculture product or commodity. Economic and social value may be 'added' to raw agricultural

20 commodities by either capturing or creating a novel value (Boland 2009). When value is said to

21 be 'captured', the raw product is transformed into a marketable product or service desired by

22 consumers, such as on-farm processing of fruit into pies, jams and jellies or marketing one's

23 products straight to the consumer. Creating value is performed when a product is differentiated 
1 from other similar products in the marketplace based on desired attributes. For example, value

2 can be created with brand identification, such as the use of organic labeling, or other certification

3 programs. In either case, producers receive price premiums for melding raw commodities with

4 socially desirable attributes. This system also selectively draws on a new set of skills often

5 distinct from raw commodity production as products are transformed, processed, or marketed.

6

\section{Research Methods}

Qualitative semi-structured interviews were used to obtain data for this study. Interview data were collected with the intention that they would provide a window into the meanings women give to agriculture work. Our goal was to investigate how Michigan women constructed meaning of their work and experienced empowerment generally, and within the boundaries of value-added agriculture systems. We began by selecting potential respondents by their presence in the state media outlets, roles they held in agricultural organizations, and on advice from Extension Educators. We then used a snowball sample to identify other potential candidates. In total, we conducted 32 interviews at either the respondent's home, farm, or coffee shop. The interviews ranged in length from one to three hours, were tape-recorded and, later, primarily transcribed. Interviews consisted of approximately 40 open and closed-ended questions covering subjects such as farm history, farm and business organization and interaction, motivations, gender dynamics, future visions, and personal demographic data. A semi-structured interview design allowed us to pay systematic attention to similarities and differences across various types of value-added enterprises. We have given each respondent a pseudonym in an effort to shield her identity.

A general inductive approach to data analysis was used. The authors systematically read and coded each transcript which resulted in the emergence of significant textual themes. The 
1 identified themes were analyzed based on their congruence with concepts from the empowerment

2 literature.

Data were collected in 2013 from women ranging in ages between 25 to 78 years. Most

4 had been actively engaged in farming for over 30 years, but years farming ranged from as little

5 as two years to 65 years. The farms with which these women are associated range in size from

6 one to 540 acres. Efforts were made to strategically include women from various parts of the

7 state. The women were located in fifteen different counties, however all were from Michigan's

8 Lower Peninsula.

9 They are united in their practice of value-added agriculture which, in Michigan, typically

10 includes an array of entrepreneurial activities as discussed above. In our study, women added

11 value to agriculture by processing fruits into cider, jams, pies and other edibles, processing lamb,

12 cheese-making, selling directly on the farm, at local farm markets, or through community-

13 supported agriculture networks, practicing agritourism, or via organic production methods.

14 There are limitations to these data that should be noted. The farm women who

15 participated in this study were initially identified by either their personal visibility as an

16 agribusiness entrepreneur or the visibility of their farm operation. They, in turn, led us to other

17 respondents who may possess similar traits. This suggests that our dataset may include a

18 disproportionate number of highly visible farm women. Moreover, the initial interviewees were

19 also identified by their connections to Co-operative Extension and for this reason these women

20 may constitute a distinctive group. As Scott as noted (1996), their affiliation with Extension may

21 imply a more conventional approach to agriculture production or a more entrepreneurial ethos to

22 agribusiness than those non-affiliated. Lastly, given the small sample size it is not possible to

23 determine if these findings represent all women farm operators. In these following sections, we 
1 offer these data to ignite further scrutiny of how women experience empowerment and the role

2 of value-added agriculture in facilitating it.

3

4

5

6

7

8

9

10

11

12

13

14

15

16

17

18

19

20

21

22

23

24

1

\section{Findings}

In this research, women articulated a number of social and economic forces that served to empower them to farm and to engage in value-added agriculture. This section provides evidence of how women cultivate "power to", "power with", and "power within" to farm generally, and to engage in value-added agriculture, specifically. We have organized this section by each of the three forms of power and we conclude each section discussing the extent to which empowerment is thwarted in the value-added agriculture context.

\section{"Power To" Farm}

Here we primarily take up two questions: what are the forces that facilitate women's power to farm; and, how does value-added agriculture, more specifically, provide a context in which farm women can effectively pursue this farming style? We define power to farm as constitutive of individual decision-making authority and control, as well as the ability to access resources and skills to operate one's farm. We begin by showing that women demonstrate the power to farm by making an individual commitment to the occupation. They access resources such as land, as well as cultivate farming knowledge and skills, via familial socialization and experiences gained during previous occupations. It was not uncommon to hear women detail the challenges they encountered in cultivating the power to farm.

Choosing Farming. A majority of the women came to farming independent of their husband's occupation or interest. They chose to farm. Most (53 percent) of the women farmed alone either as a result of being unmarried or having a husband employed full-time off the farm. 
1 When there was a spouse present, he may have 'helped' from time to time during intensive

2 periods, but had very few on-going farm responsibilities. In only 27 percent of the cases did the

3 respondents indicate that the male was the primary farm operator and only six percent farmed

4 jointly.

Following their passion to farm, for many, was an old dream, and for others a more recent

6 ambition, but in each case, women highlighted their role in the decision to farm. When we asked

7 the women to reflect on their motivations for farming, they frequently emphasized three issues:

8 farming was a personal aspiration; they had dreamed of farming for many years; and, they were

9 the primary decision-makers and in control of their operations.

As a nurse I had the chance to see so many illnesses caused by lifestyle choices and I began to see diet as so important to health. Gradually, I started raising herbs as a hobby and for gift-giving, but eventually I chose to leave my nursing job for full-time farming, but I always wanted my business to be a community effort, to bring people in and to teach... My husband has always been supportive, but this was my dream (Rita).

I had worked as a medical professional for many years and I wanted a change. I dreamed of being a cheesemaker and having a creamery on a small farm and raising sheep. My husband would like to help when he retires, but, for now, he still works (Rhonda). and running the farm stand before we got married. My husband always worked off the farm as a tool and die maker, but he helps on the weekend (Grace). 
1 These women view themselves as the primary or sole decision-maker in either the production

2 end of the operation or some other area of the farm, such as processing (e.g., running the cider

3 house, farm market, restaurant). The quotes above suggest that the women were able to make the

4 career choice to farm, as well as exercise authority in the daily management of their farm

5 operation. However, they told us this ability was facilitated by the acquisition of specific skills

6 and resources made possible by familial ties and previous careers.

$7 \quad$ Accessing resources and skills. For many, the power to farm was facilitated by accessing

8 resources and skills critical to the practice of agriculture, in general, and value-added agriculture

9 more specifically. Not surprisingly, women stressed the importance of land and capital access as

10 vital. Land and capital have always been barriers to entry into farming and these resources are

11 particularly difficult to access for beginning and minority populations. The power to farm was

12 enabled by families who helped them access resources. Among primary farm operators (76

13 percent), forty-one percent inherited or purchased farmland from the family of her ancestry. Beyond land, women credited family ties for passing on a passion for farming, as well as

15 skills, knowledge, and entrepreneurial opportunities that launched their farm careers. Women

16 described being socialized into the role of farmer, in the same way as male farm operators have

17 historically reported, but contrary to their male counterparts, many attributed significant

18 influence to their mother - who uniquely prepared them to practice value-added agriculture. Grace is a good example of those women motivated by family heritage. At 78 years old,

20 she tells us she has been farming since the age of two to emphasize the work she was expected to

21 do with her parents. She traces her farm business lineage back to her teenage years when, at the

22 suggestion of her mother, she turned her equine hobby into an entrepreneurial activity. At age 15,

23 Grace began organizing hayrides and horse riding events for profit, and when she married at age 
1 19, she followed her mother's advice once again and established a roadside fruit and vegetable

2 market. Later, she began adding value to the produce by processing jams and jellies which she

3 sold at her roadside stand. Grace tells us, "I could not have done it if it weren't for my parents.

$4 \quad$ Using the farm to make money was my mother's idea, and they helped us buy the farm when

5 they retired."

$6 \quad$ Melissa also has a farming heritage; she grew up working alongside her mother in a

7 seasonal farm stand located on a busy highway near Lake Michigan. "We kids were expected to

8 work along with her, so a few years after we got married mom decided to retire and she asked me

9 if I wanted to take it over.” Today, Melissa produces cherries which she and her staff transform

10 into value-added products and sell at the same market she inherited from her mother. Her

11 husband helps from time to time, but, like Grace's spouse, he has an unrelated off-farm career.

In a similar way, Maxine also inherited a farm market from her mother whom she

13 describes as value-added agriculture "pioneer".

Dad grew the cherries and mom baked pies. She would load the trunk of the '68 GMC, drive over to Hwy 57, set up card tables and saw horses to sell cherries, pies, and jams for two and a half weeks, then reopen a few weeks later for peach season, and then again for apples. I guess I learned a lot from her, because we had to help all summer. This matriarchal influence appears rare in the sociological literature on farm succession.

20 Overein 2013), with most emphasis being placed on knowledge transfer and passing down the 21 farm from father to son (Peter et al. 2005). Our research suggests that mothers may be neglected

22 actors in farm succession, as they play a significant role in socializing their daughters, not only to 23 farm, but to pursue value-added agriculture, specifically. Haugen and Brandth (1994) found that 
1 farm women often downplay relations with mothers and accentuate relations with fathers to align

2 themselves with masculinist traits perceived necessary for validation in agriculture. Conversely,

3 the women in this study accentuated the role of their mothers by recounting stories of mothers

4 who taught them culinary, marketing, and organizational skills necessary to transform raw

5 products into value-added consumables, which, in turn, prepared them socially and economically

6 to respond to the post-productionist turn in agriculture. This suggests that farm women, as

7 mothers, can be empowering agents preparing their daughters through socialization, to obtain the

8 aspiration, skills, and knowledge to become farm operators in adulthood, and to become value-

9 added entrepreneurs, in particular.

Other women reported turning to farming as a second, or "encore", career. The power to

11 farm for these women was cultivated through previous careers that provided both valuable

12 capital and skills. A number of women noted that the power to farm was constrained by lack of

13 capital and years spent saving money in other careers was necessary to eventually be able to

14 farm, or to turn to farming full time. "I put in my time as a nurse for 28 years, waiting for the day

15 we could start our own farm. We had to save a lot of money," says Carolyn.

In addition to capital, women also attributed the power to farm to their previous careers

17 which provided the context in which they developed the human capital valuable to their farming

18 career. Women described skills such as bookkeeping, marketing, advertising, photography,

19 nursing, and teaching that they routinely put to use in their farm operation. For instance, Leigh

20 says she uses her former "school teacher skills everyday day. "From managing our two

21 employees, to teaching bread-baking classes, to leading tours of the mill, I'm always teaching."

22 While these skills are not necessarily unique to value-added agriculture, they are more critical for

23 operations that demand a farm-public interface. Value-added agriculture creates the context for 
1 the utilization of skills and knowledge more likely to be part of women's social-cultural tool-kit,

2 cultivated within the domestic sphere or within female-dominated occupations. In this way, it

3 makes room for skills and knowledge deemed feminine, but does not disrupt the traditional

4 gendered division of labor prevalent in rural communities.

Cultivating "power to". The power to farm was due to women's access to land, familial

6 resources, and human resources developed in previous careers. This reinforces findings by

7 Pilgeram and Amos (2015) who underscore the importance of social location and life course as

8 determinants of farming opportunities. A number of respondents acknowledged the importance

9 of their husband's income. Among those who were married, 39 percent have husbands who

10 contribute to the fiscal health of farm from their off-farm income. Veronica says her "husband

11 provides good financial support which helps me run my business, but I still cannot get an income

12 from it after three years." Not only do some women not have full control over the resources

13 required to sustain value-added agriculture, but this condition facilitates a relationship of co-

14 dependency of women on men.

Moreover, as previously stated, value-added agriculture accentuates skills typically

16 affiliated with women's caretaking. In this way, value-added agriculture trades

17 disproportionately on traditional gender roles which, in such cases, are presented to the public for

18 commodification. Incorporating traditional gender roles into value-added agriculture may

19 leverage economic opportunity, but it also functions to constrain women's ability to deviate from

20 conventional gender expectations. In this way, it continues the extension of women's assignment

21 to the domestic sphere. It may also reaffirm a gender system in which traditional views of

22 femininity are valued. Coding such work as feminine, may be responsible for the lower revenue

23 that the respondents reported, and for their persistent reliance on male incomes to sustain their 
1 operations. In this regard, their involvement in value-added agriculture may not foster the desired

2 social change needed to sustain the power to farm.

These interviews suggest that women find the power to farm in their exercise of agency

4 to choose farming, as well as in their ability to access land. Yet, they cultivate the power to farm

5 value-added agriculture specifically, in the farming knowledge and skills gained via familial

6 socialization and experiences achieved during previous occupations. However, reliance on

7 gendered skills and knowledge typically found in value-added agriculture operations, along with

8 co-dependence on male incomes, may create only tenuous empowerment opportunities. These

9 conditions do not provide women the opportunity to act in their own interests, but may stimulate

10 erratic and unintended disruptions to the empowerment process. The following analysis delves

11 deeper by exploring the ways in which value-added agriculture enables women to construct

12 power with others.

\section{"Power With" Others}

"Power with" signals the importance of empowerment as a collective journey bringing

16 together individuals who share complementary interests (Charlier 2006; Kabeer 2001; Umut

17 Bespiran 2011). Previous research suggests that farm women create power in their relations with

18 other women, through agricultural organizations or networks (Annes and Wright 2015;

19 Hassanein 1999; Trauger 2001; Wells 1998) which can be a source of shared interests, as well as

20 solidarity. Likewise, women in this study reported that they were motivated to farm, in part, out

21 of a desire to connect with others, making the farm/public aspect of much of value-added

22 agriculture an attractive choice. However, the connection they accentuated was less likely the

23 desire to connect with other like-minded farmers, but a desire to establish ties with those outside 
1 of agriculture. Therefore, in this section, we explore how women use value-added agriculture to

2 create "power with" customers or farm guests. The solidarity farm women cultivate within value-

3 added agriculture is expressed in two ways: through the development of personal connections, as

$4 \quad$ well as a desire to educate consumers about agriculture.

Connecting with consumers. Many women were motivated to pursue value-added

6 agriculture as a way of embedding themselves and their farms in a broader social network.

7 Charlotte centralizes the importance of community when she says, "It was important to us to

8 build a farm that was open to the public so we could share our land with other people." Leslie

9 describes her work on her mint farm as "planting dreams, cultivating friendships and harvesting

10 goodness." Grace too punctuates her need for community when she says, "I am not interested in

11 raising corn and soybeans like these farmers around here. I am a people person, I need to talk to

12 people." In each of these cases, the role of community embeddedness rises to the foreground,

13 where the farm is regarded as more than an economic vehicle, but a civic instrument to serve 14 social interests as well.

Although the desire for community ties was a reoccurring theme, the ways in which some enacted it complicates interpretation. We visited Jackie's farm on a bright spring day and she met

17 us at our car looking ever the picture of the early 1900s farm fashion. Her silver hair tied into a

18 sleek bun and her ankle length cotton print dress and coordinating apron were part of her

19 costume meant to enhance her performance aimed at transporting us to a different way of life.

20 She begins immediately to welcome us to her "life on the farm", telling us her goal is to give her

21 u-pick customers a chance to "experience a life they are not exposed to" and to develop a

22 relationship with farmers. "They want a story," she tells us, and her historical costume helps her

23 spin this narrative. 
They want to feel connected and I do too. We are not in the business to entertain ... we are here to educate and connect with city dwellers and to help them experience a little slice of rural life.

Jackie's language reinforces her desire for community and to educate which is important to both her sense of self and desire to establish a common agricultural consciousness with her customers. Yet, she pursues this solidarity in costume which objectifies herself and her farm operation. By 'dressing the part', this woman has positioned herself as a physical object to be looked at and evaluated on the basis of appearance, rather than on any competence-based measures. She becomes a prop and her farm a stage for what may be interpreted as a choreographed performance.

Dorothy echoes a desire for connection. On her well-manicured turn-of-the-century 32 acre farm she combines a farm tour with retail sales of pottery created in her barn-turned art gallery/studio. Her motivation is to share her up-bringing and to get people to think about where their food comes from and support local economies ... I tell people this is a Hollywood farm; that it's not real, but I am trying to reconstruct the fairytale image in my head of rural life from my childhood. Charlotte's Webb was my favorite book as a child and I am trying to resurrect those images.

Dorothy also wants tourists to develop a deeper understanding of agriculture and rural life and she uses popular myths to do so. Like Jackie, she presents a fictional representation of rurality that trades on nostalgia and, in doing so, underscores imagery over realism. While images of rural space can be informative in understanding the worldviews of women, when constructed for the purpose of 'educating' others less familiar with rural people and places, they can confound 
1 and stimulate tension (Yarwood 2005). In this way, power with others is difficult to discern. It

2 may be only an approximation, disguising fragile or artificial bonds.

Educating consumers. Ninety percent of the women reported feeling very strongly about

4 educating consumers about the challenges facing modern agriculture and farm families. "It's a

5 passion of mine, teaching people," Ava said. "I use the time together to talk about wider issues in

6 the Michigan economy, the opposition between big farms and small ones, and the importance of

7 communities working together."

8 Dorothy described two types of guests who visit her agritourism operation: those who are

9 "a totally naïve group;" and others who are "very knowledgeable, but are freaked out and trying

10 to find answers... Both groups need educating, it is just a different kind." Katherine adds a

11 gendered distinction to the education role when she says, "It's all about educating, the guys get

12 frustrated with customer questions, but this is a real chance to educate them." Similarly, Patricia

13 believes

people have a very idealistic view of rural life. They are very disconnected from their food; they get their information on-line and it is not accurate. They need more education...Education is primarily what we do.

17 Perhaps Leigh's is the most ambitious goal.

We wanted to save the world. We thought by increasing the supply of organic food and educating people we might help accomplish that. People who come here are looking for a personal connection with their food and I need a personal connection with them. Our tours, cooking classes, dinners, festivals help me connect too.

22 Developing social relations with consumers satisfied needs for community among the

23 respondents, but it was also viewed as a form of public service to their community. Repeatedly, 
1 respondents described consumers as deficient in essential agrifood knowledge and feeling

2 obligated to fill this gap. Tammy called it a "civic responsibility." "I think I have a duty to

3 educate them."

4 These collective ties established with consumers differ from the solidarity development

5 scholars envision when discussing women in the Global South collectively, nonetheless they

6 demonstrate the ability of Michigan farm women to exercise "power with" others within the

7 value-added-agriculture context. In this way, value-added agriculture provides women with the

8 opportunity to overcome isolation, establish social ties, demonstrate their specialized knowledge,

9 and provide a vital civic function. The extent to which these ties are reciprocated and that

10 learning takes place, however, is unknown.

11 Cultivating "power with". The importance of sharing the culture of farm life and

12 connecting with others was not only a significant draw to value-added-agriculture, but was

13 deemed a core element for many which they saw as contributing to their own personal

14 empowerment, as well as to broader social welfare. Cultivating "power with" others was found

15 to fill an important need among farm women, but, at the same time, such connections were not

16 innocuous. The manner in which some farm women went about disseminating farm information

17 may distance themselves from any empowerment potential. Reliance upon cultural imaginary,

18 costumes, or fictional narratives to initiate this connection - giving consumers the story they

19 want to hear - may backfire. Portraying farming in ways that caricature agriculture perpetuates

20 stereotypes that eclipse the dynamism of the modern agrifood system, rife with tension and

21 struggle. Peddling in imagery is unlikely to lead to a meaningful connection with others for the

22 storytellers, nor can it produce a profound understanding of agriculture and rural life for

23 consumers. Symbols and narratives rooted in idealized or romantic imagery, rather than accurate 
1 and complex portrayals of contemporary challenges farmers face or the tensions inherent in rural

2 life, can only tear at the fabric of trust and undo any prospective community building inroads.

4 "Power Within" the Self

In this section, we discuss how value-added agriculture may activate "power within."

6 Specifically, we ask how women develop a stronger sense of self and to what extent their

7 involvement in value-added agriculture fosters the practice of reflexivity and raises

8 consciousness regarding structures of oppression. We show that as value-added producers, many

9 women reported experiencing a transformation in their identities; increasingly seeing themselves

10 as farmers and adopting this language as a professional identifier. But, while many associated

11 positive socio-psychological benefits to the practice of value-added agriculture, others struggled

12 in this regard.

13 Socio-psychological benefits. A majority of women stressed the socio-psychological

14 benefits of value-added agriculture, especially in the context of their interactions with others.

15 Time and time again, we heard it was "enjoyable", "rewarding" or "personally fulfilling." "I find

16 it fun and I think it is important work and I am good at it. It gives me a lot of pride to share my

17 knowledge and to have others take our life here seriously," Angela says. Others described the

18 educational component of their work as "a fascinating process" that was "personally uplifting"

19 and "life changing when you see people make connections." "It makes me feel good to educate

20 people and know I helped them develop as a person,” says Carolyn.

From this perspective, value-added agriculture provides women the opportunity to

22 challenge traditional representations of farm women, allowing them to appear as competent

23 professionals. Positive socio-psychological benefits raise the question as to whether women are 
1 drawn to value-added agriculture precisely because it prizes their culturally-prescribed gendered

2 skills and creates the context for them to use these talents in ways other farming systems do not.

3 Such conclusions are supported by motivation theories which posit that individuals are more

4 likely to be attracted to activities in which they perceive themselves as being highly skilled or 5 competent (Harter 1978; Nicholls 1984).

$6 \quad$ Many women went beyond describing their work as satisfying to attach meta-physical

7 attributes to it. Claims that they found their farm work to be "sacred" or "spiritually

8 invigorating" were common. Rita's religious values are closely woven into her one-woman farm

9 operation. As a former nurse, she describes her work as "food evangelism", helping her

10 customers find good health and spirituality through her farm. She is convinced that "God wants

11 me to be here, to do this work. I see this as a ministry of care as I connect with others." She

12 shares her theory that many women are entering value-added agriculture as an existential

13 exercise - "to find quiet time, to recharge themselves."

Crafting the farmer identity. Almost eight in ten of the women self-identified as farmers.

15 These findings support research showing a growing inclination among women to identify as

16 farmers (Braiser et al. 2014). This group reported making most of the decisions concerning the

17 farm, conducting most, if not all the labor, being responsible for the day-to-day maintenance of

18 the operation, conducting financial management tasks, and exploring new business outlets.

Also in keeping with previous research (Barberchek et al. 2009), in spite of this tendency

20 to identify as a farmer, many respondents continued to struggle with the social acceptability of

21 such an identity. As one woman put it, "women don't get much respect in farming. I used to sell

22 wholesale and the clients wouldn't want to talk to me. They were always looking for Brad

23 [husband]." Leslie agrees, saying she also feels "like a farmer, but others see me as a caretaker." 

personal identity to facilitate smooth social relations with clients. Tammy, for instance, avoids publicly identifying as a farmer even though this is how she sees herself and her role on the farm. I think people in this area would think I was mocking farmers if I called myself a farmer publically. I feel I am, but they don't see me that way. They are always looking to talk to my son. He's the 'real' farmer.

On the other hand, Betty Jo says others perceive her as a 'real' farmer, but she is less comfortable with this identity. As a result, she has developed tactics for managing an impression of herself as a competent farmer that meets local social expectations. I go back and forth on that issue. I guess I don't really feel like a real farmer because I don't have a garden, I don't know how to can [preserve]... sometimes I feel like a fake. Customers expect me to have certain knowledge I do not have. Often they ask how to can something, how much product to buy to make something, and I don't know. I was embarrassed to say 'I don't know' so I made a cheat sheet that shows how much fruit you need to make a pie or jams or whatever.

These findings suggest there remains considerable public speculation regarding women's ability to farm. For many, the role of farmer continues to be perceived to be in contrast to role expectations for women. It also reinforces the notion that women's agency is constrained by the organizational form prescribed. Nieva and Gutek (1981:132) argue that when women enter male-dominated fields they are unlikely to be able to significantly alter work roles, as "social structures heavily shape the options and tools available to them."

The ability to think reflexively about sources of oppression is evident by women who are cognizant of customer's efforts to categorize organic from non-organic farmers. Katherine stated 
1 that she was “starting to notice younger people being more snobbish to us since we don't do

2 organic. They think they know better how to raise apples than we who have been doing it for

3 years." Betty Jo shared a similar experience.

$4 \quad$ More and more people are asking about organic and they can be a bit judgmental. I am against organic in Michigan because it rains here. It is not a smart way to farm...We can't feed the world that way. Wet trees create fungus and you have to spray to control fungus. Some are snotty about it. It is like a religion for them. They are not going to hear your side of the story...We do IPM but for some people that's not enough. People really don't want worms, but they want a perfect world and perfect fruit, but they can't have both. In each of these cases, we can see how women construct a sense of self in alignment with the 11 social context in which they must navigate that is imbued with its own set of assumptions about

12 what does or does not constitute a farmer. These women appear to experience cognitive

13 dissonance and must negotiate both social expectations and practices produced by outsiders and 14 their own preferred self-image. That our sense of self is constructed in part from social 15 experience with others is not surprising from the perspective of classical socio-psychological theory (Mead 1934). What farm women think of themselves is significantly shaped by "the

17 looking glass" of consumers, agritourists and others with whom they interact. However, this 18 ability to take the role of the other demonstrates their ability for reflexivity as women see themselves as both subject and object. Cultivating "power within”. Given that value-added agriculture often rewards skills

21 disproportionately held by women and provides a venue to showcase them, it can enhance

22 feelings of competence and self-esteem. At the same time, some of the women reported being 23 denied the recognition of farmer, and others who were granted it felt undeserving, needing "cheat 
1 sheets" to fulfill local expectations. This reinforces Saugères (2002) argument that farm women

2 are often perceived as "incomplete farmers," lacking both physical, psychological, and social

3 attributes necessary for farming.

$4 \quad$ Findings about who farm women are and how they are allowed to portray themselves

5 continue to be negotiated under value-added agriculture as it can fail to provide the supportive

6 environment for the empowerment of women. This suggests that given the context, the ability of

7 value-added agriculture to nurture "power within" the self, as well as challenge it, is uneven. The

8 persistence of this socio-psychological struggle demonstrates the lingering forces of "power

9 over" as groups, such as customers and guests, influence how women perceive themselves.

\section{Discussion}

While the empowerment of women is evident in all three forms of power presented in this

13 paper, it does not go unchallenged. In this section, we discuss insights from these findings and

14 their prospects for aiding the future empowerment of rural women.

Like much of the literature on sustainable agriculture (Sumner and Llewelyn 2011;

16 Trauger 2004), we found that value-added agriculture also provides a context in which women

17 are more likely to be represented, but in the case of Michigan, this relationship is not new.

18 Women's empowerment in Michigan agriculture started long before the relatively recent rise of

19 alternative agriculture. Michigan farm women pioneered value-added agriculture in their efforts

20 to expand the economic activity of the household, rooted in the heterosexual partnership. Yet, the

21 rise in alternative food systems and the localism movement have accentuated these contributions

22 and punctuated women's visibility. In addition to laying the foundation for a value-added 
1 agriculture, they socialized future generations of women into this work, opening opportunities

2 for sustained participation.

We found these women to have autonomy in the decision-making process, and

4 considerable control over their farms. Their access to farmland, knowledge and skills via familial

$5 \quad$ ties and socialization and first careers has provided greater control over their fates to experience

6 the power to farm. Their cultivation of power with others allows them to satisfy needs for social

7 relations and community and the growing embrace of a farmer identity also speaks to critical

8 socio-psychological aspects of the empowerment process to be found in value-added agriculture.

9 Women appear to be more responsible for the infrastructure and services that allow

10 others to consume the rural through the purchase of place-based products and experiential

11 activities which all draw on their gendered skills and knowledge. This surely is a signal that the

12 value for women's knowledge is rising and, thus, the empowerment potential in value-added

13 agriculture. The incorporation of a care ethic in organic production systems as well as the

14 valorization of natural and cultural amenities is, likewise, considered by some to have uniquely

15 positioned women to capitalize on these new markets (Jarosz 2011).

However, increased visibility and activation of traditional gendered roles may be

17 indicators of a more troublesome nature. Could women's visibility in value-added agriculture

18 signal their persistent invisibility? We see significant inroads to empowerment which we have

19 summarized above, that, while necessary, remain insufficient markers of empowerment.

20 One feature notable in women's struggle to gain "power to", "power with", and "power

21 within" is the unevenness of the empowerment process. This requires interrogation of the ways

22 in which their visibility and participation is structured. More information is needed on how

23 structural arrangements condition opportunities in value-added agriculture. For example, 
1 continued reliance upon male incomes, years spent saving money in first careers, as well as

2 family inheritances, capitalizing on culturally expected gender roles, molding ones identity to fit

3 conventional norms are cultural signposts that empowerment does not proceed unabated. This

4 suggests that value-added agriculture may not provide the individual with the empowerment

5 potential we assume.

$6 \quad$ Findings also make clear that not all visibility is beneficial. Rendering visible and

7 performing traditional gender roles may also constitute an essentialist interpretation of women's

8 work, denying women expression of their own subjectivities. We discovered women's ability to

9 be seen as a subject obscured in multiple ways. For example, when outsiders reserve the identity

10 of farmer for males, women are denied agency. At the same token, when women 'fake' a farmer

11 identity and construct a disingenuous persona that is intended to 'dress the part', or possesses

12 knowledge one does not legitimately hold in order to align oneself with normative expectations,

13 they subvert their own empowerment potential. Such struggles, and especially the tendency by

14 some to acquiesce to the expectations of others, suggests that our respondents were stymied in

15 their ability to cultivate "power within." The manufacture of expectant identities becomes just

16 another marketing tool that trades on stereotypes and rose-colored ruralities. Both are forms of

17 "othering" which distance rural populations from the non-rural, and in doing so, women become

18 objects or representations of the rural, rather than subjects. Instead of becoming empowering, in

19 certain circumstances, value-added agriculture may become disciplinary and coercive by pushing

20 women to adopt, and to be confined to, a gender and a rural identity that is externally prescribed.

21 In both extolling rural imaginary and denying their own sense of self, farm women privilege the

22 discourse of the non-farm [urban] population to depict rural lives. Such objectification can only

23 lead to the reproduction of "power over," rather than the realization of any actual empowerment. 

challenging cultural misrepresentations of women which portray them as incomplete farmers,

3 they are once again rendered culturally and socially invisible. By perpetrating such imagery and

4 partial realities, many of our research participants are unable to identify the true source of their

5 oppression, limiting their ability to cultivate "power within." These findings suggest that while

6 women are increasingly engaged in value-added agriculture and assuming structural positions of

7 authority and decision-making, ideological and political forces outside of agriculture have not

8 kept pace, and when presented with challenges to their roles, women often acquiesce to social 9 norms.

The aim of this paper has been to apply the concept of empowerment to farm women in

12 the Global North. Mainly elaborated in the context of the developing world, we extended the 13 conceptualization of empowerment to probe the experience of farm women in North America.

14 Exploring the question of whether Michigan women find in value-added agriculture an avenue

15 for empowerment, we found uneven evidence for developing “power to," "power with," and

16 "power within." While inroads have been made, the extent to which value added-agriculture

17 constitutes a venue for farm women's empowerment is complex, multifaceted, and requires

18 constant negotiation. Women's engagement in value-added agriculture creates a space for

19 decision-making and control, but it also can be organized in such a way as to impede the

20 empowerment process by confining women to specific social locations that may reify existing

21 oppressive normative structures.

Many debates within the empowerment literature focus attention on 'how much'

23 empowerment is attained as a result of some intervention or social transformation. We are left to 
1 conclude that the accolades often bestowed upon value-added agriculture as both a vehicle for

2 sustainable rural development generally, and for women's empowerment more specifically, may

3 be overstated. This question clearly requires more empirical research and may be expected to

4 differ by region and the presence of competing economic opportunities. This study suggests that

5 of equal importance is the investigation of different kinds of involvement and their effects. By

6 exploring the kinds of involvement to which women have access or create, we are able to

7 discover how agriculture systems affirm or challenge empowerment opportunities. A fuller

8 understanding of how value-added agriculture both contributes to and impedes farm women's

9 empowerment awaits more scrutiny. Given the growing demand for value-added agriculture and

10 the rising number of women taking their place in agriculture, the question of gender

11 empowerment is critical to the social sustainability of the food system.

12

13

14

15

16

17

18

19

20

21

22

23 


\section{REFERENCES}

Afshar, H. 1998. "Introduction: Women and Empowerment." Pp. 1-10 in Women and Empowerment: Illustrations from the Third World, edited by H. Afshar. London: Palgrave Macmillian.

Ali, R. 2013. "Empowerment Beyond Resistance: Cultural Ways of Negotiating Power Relations.” Women's Studies International Forum 45:119-126.

Allen, P. and C. Sachs. 2007. "Women and Food Chains: The Gendered Politics of Food." International Journal of Sociology of Agriculture and Food 13(1):-23.

Alston, M. 2003. "Women in Agriculture: The New Entrepreneurs." Australian Feminist Studies 18(41-52).

Annes, A. and W. Wright. 2015. "Creating a Room of One's Own?: French Farm Women, Agritourism and the Pursuit of Empowerment." Women's Studies International Forum 53:1-11.

Barbercheck, M., K. Brasier, N. E. Kiernan, C. Sachs, A. Trauger, J. Findeis, A. Stone, and L. Moist. 2009. "Meeting the Extension Needs of Women Farmers: A Perspective from Pennsylvania." Journal of Extension 47(3).

Bock, B. 2004. “Fitting in and Multi-tasking: Dutch Farm Women's Strategies in Rural Entrepreneurship.” Sociologia Ruralis 44(3):245-60.

Boland, M. 2009. "What is value-Added Agriculture? Agricultural Marketing Resource Center. Retrieved Sept. 08, 2016 at: http://www.agmrc.org/business_development/getting_prepared/valueadded_agriculture/ar $\underline{\text { ticles/ }}$

Brandth, B. 1995. "Masculinity in Transition: Gender Images in Tractor Advertisements." 
Journal of Rural Studies 11(2):123-33.

Brandth, B. and M. S. Haugen. 2010. "Doing Farm Tourism: The Intertwining Practices of Gender and Work." Signs: Journal of Women in Culture \& Society 35(2):426-446.

_. 2011. "Farm Diversification into Tourism - Implications for Social Identity?" Journal of Rural Studies 27:35-44.

Brandth, B. and G. Overrein. 2013. "Resourcing Children in a Changing Rural Context: Fathering and Farm Succession in Two Generations of Farmers." Sociologia Ruralis 53(1):95-111.

Brasier, K., C. Sachs, N. Kiernan, A. Trauger and M. Barbercheck. 2014. "Capturing the Multiple and Shifting Identities of Farm Women in the Northeastern United States.” Rural Sociology 79(3):283-309.

Cánoves, G., M. Villarino, G K. Priestley and A. Blanco. 2004. "Rural Tourism in Spain: An Analysis of Recent Evolution.” Geoforum 35(6):755-69.

Charlier, S. 2006. 'L'Analyse de l’Empowerment des Femmes qui Participent à une Organisation de Commerce Equitable: Une Proposition Méthodologique.” Pp.87-110 in Economie Solidaire et commerce équitable. Acteur et actrices d'Europe et d'Amérique latine, edited by C. Auroi and I. Yepez. Louvain: Presse Universitaires UCL/IUED.

Che, D., G. Veeck, and A. Veeck. 2005. "Agriculture and the Selling of Local Food Products, Farming, and Rural America Tradition to Maintain Family Farming Heritage.” Pp. 109121 in Rural Change and Sustainability: Agriculture and Environment and Community, edited by S. Essex, A.W. Gilg and R. B. Yarwood. Wallingford: CAB International. Dahal, S. 2013. "Power, Empowerment and Community Radio: Media by and for Women in 
Nepal." Women's Studies International Forum 40:44-55.

DeLind, L. and A. Ferguson. 1999. “Is This a Women's Movement? The Relationship of Gender to Community Supported Agriculture in Michigan." Human Organization 58(2):190200.

Doering, C. 2013. "Breaking the 'Grass Ceiling': More women are Farming. USA Today.” Retrieved on December, $1^{\text {st }}$ 2014. Retrieved on March 13, 2015 (http://www.usatoday.com/story/news/nation/2013/03/17/women-farmersincreasing/1993009/).

Fairweather, J. R., L.M. Hunt, C. Rosin and H.R. Campbell. 2009. “Are Conventional Farmers Conventional?: Analysis of the Environmental Orientations of Conventional New Zealand Farmers." Rural Sociology 74(3)430-54.

Fink, D. 1992. Agrarian Women: Wives and Mothers in Rural Nebraska, 1880-1940. Columbia, SC: The University of South Carolina Press.

Garcia-Ramon, M. D., G. Canoves and N. Valdovinos. 1995. "Farm Tourism, Gender and the Environment in Spain.” Annals of Tourism Research 22(2):267-282.

Gasson, R. 1980. "Roles of Farm Women in England.” Sociologia Ruralis 20(3):165-180.

Hall, A. and V. Mogyorody. 2007. "Organic Farming, Gender and the Labor Process." Rural Sociology 72:289-316.

Harter, S. 1978. "Effective Motivation Reconsidered: Toward a Developmental Model." Human Development 1:34-64.

Hassanein, N. 1999. Changing the Way America Farms: Knowledge and Community in the Sustainable Agriculture Movement. Lincoln, NE: University of Nebraska Press.

Haugen, M. S. and B. Brandth. 1994 "Gender Differences in Modern Agriculture. The case of 
Women Farmers in Norway. Gender \& Society 8(2):206-229.

Jarosz, L. 2011. "Nourishing Women: Toward a Feminist Political Ecology of Community Supported Agriculture in the United States.” Gender, Place \& Culture 18:307-26.

Jellison, K. 1993. Entitled to Power: Farm Women and Technology, 1913-1963. Chapel Hill: University of North Caroline Press.

Jensen, J. 1991. Promise to the land. Albuquerque, NM. University of NM Press.

Kabeer, N. 1999. "Resources, Agency, Achievements: Reflections on the Measurement of Women's Empowerment." Development \& Change 30:435-464. . 2001. "Conflicts over Credit: Re-Evaluating the Empowerment Potential of Loans to Women in Rural Bangladesh.” World Development 29(1):63-84.

Kiernan, N.E., M. Barbercheck, K J. Brasier, C. Sachs, and A. R. Terman. 2012. "Women Farmers: Pulling Up Their Own Educational Boot Straps with Extension.” Journal of Extension 50(5):5RIB5. http://www.joe.org/joe/2012october/rb5.php.

Knudson, W. and C. Peterson. 2012. “The Economic Impact of Michigan's Food and Agriculture System.” Working Paper No. 01-0312. Michigan State University Product Center. Retrieved on March 13, 2015 (http://productcenter.msu.edu/uploads/files/MSUProductCenter2012EconomicImpactRep ort1.pdf).

Krauss, B. 1999. A Time to Remember: A History of the Jewish Community in South Haven. Allegan Forest, Michigan: The Priscilla Press.

Leckie, G. 1996. “They Never Trusted Me to Drive': Farm Girls and the Gender Relations of Agricultural Information Transfer." Gender, Place \& Culture 3(3):309-25.

Leipins, R. 1998. “'Women of Broad Vision': Nature and Gender in the Environmental 
Activism of Australia's 'Women in Agriculture' Movement." Environment and Planning A 30:1179-1196.

Little, J. 2002. Gender and Rural Geography. London: Pearson.

Lockie, S. and D. Halpin 200. “The 'Conventionalisation' Thesis Reconsidered: Structural and ideological Transformation of Australian Organic Agriculture.” Rural Sociology 45:284303.

Lyson, T. 2004. Civic Agriculture: Reconnecting Farm, Food, and Community. Baltimore: Tufts University Press.

Malhotra, A. and S. Shuler. 2005. “Women's Empowerment as a Variable in International Development.” Pp. 71-88 in Measuring Empowerment: Cross-Disciplinary Perspectives, edited by D. Narayan. Washington D.C.: World Bank, Gender and Development Group.

Malhotra, A., S. R. Schuler, and C. Boender. 2002. “Measuring Women's Empowerment as a Variable in International Development. Background Paper Prepared for the World Bank Workshop on Poverty and Gender: New Perspectives. Retrieved 3/15/15 at http://siteresources.worldbank.org/INTGENDER/Resources/MalhotraSchulerBoender.pdf

McNally, S. 2001. "Farm diversification in England and Wales - what can we learn from the farm business survey?” Journal of Rural Studies 17(2):247-257.

Mead, G. H. 1934. Mind, Self, and Society. Ed. by Charles W. Morris. Chicago: University of Chicago Press.

Meares, A. 1997. "Making the Transition from Conventional to Sustainable Agriculture: Gender, Social Movement Participation, and Quality of Life on the Family Farm.', Rural Sociology 62:21-47.

Murthy, R, J. Sagayan, R. and S. Nair. 2008. “Gender, Efficiency, Poverty Reduction, and 
Empowerment: Reflections from an Agriculture and Credit Programme in Tamil Nadu, India." Gender \& Development 16(1):101-116.

Narayan, D. 2005. Measuring Empowerment: Cross-Disciplinary Perspectives. Washington: The World Bank.

Neth, M. 1995. Preserving the Family Farm. Baltimore: Johns Hopkins University.

Nicholls, J. G. 1984. “Achievement Motivation: Conceptions of Ability, Subjective Experience, Task Choice and Performance.” Psychology Review 91:328-46.

Nieva, V. F. and B. A. Gutek. 1981. Women and Work: A Psychological Perspective. New York: Praeger.

Oxaal, Z. and S.Baden. 1997. “Gender and Empowerment: Definitions, Approaches and Implications for Policy." Briefing prepared for the Swedish International Development Cooperation Agency (SIDA), Report number 040. Brighton, UK: Bridge Development - Gender, Institute of Development Studies.

Pearson, J. 1979. “Research Note on Female Farmers.” Rural Sociology 44:189-200.

Peter, G., M. Bell, S. Jarnagin and D. Bauer. 2005. "Farm Dads: Contemporary Challenges to Fatherhood in the Fields of the Midwest.” Pp. 235-253 in Situated Fatherhood: Negotiating Involvement in Physical and Social Contexts, edited by W. Marsiglio, K. Roy and G. Fox. Rowman and Littlefield.

Pilgeram, R. and B. Amos. 2015. "Beyond 'Inherit It or Marry It': Exploring How Women Engaged in Sustainable Agriculture Access Farmland.” Rural Sociology 80(1):16-38. Preibisch, K. and E. E. Grez, 2010. "The Other Side of el Otro Lado: Mexican Women and Labor Flexibility in Canadian Agriculture.” Signs: Journal of Women in Culture and Society 35(2):290-316. 
1 Rosenfeld, R. 1985. Farm Women: Work, Farm, and Family in the U.S. Chapel Hill, NC. University of NC Press.

Rosin, C. and H. Campbell. 2008. "Beyond Bifurcation: Examining the Conventions of Organic Agriculture in New Zealand.” Journal of Rural Studies 25:35-47.

Rowlands, J. 1995. “Empowerment Examined.” Development in Practices 5(2):101-107. 1997. Questioning Empowerment. Oxford: Oxfam GB.

Sachs, C. 1983. The Invisible Farmers. Totowa, New Jersey: Rowman and Allanheld.

Sachs, C. and. M. Alston. 2010. “Global Shifts, Sedimentations and Imaginaries.” Signs: Journal of Women, Culture and Society 35(2):277-288.

Saugeres, L. 2002. “'She's Not Really a Woman, She's Half a Man': Gender Discourses of Embodiment in a French Farming Community." Women's Studies International Forum 25(6):641-50.

Scott, S. L. 1996. "Drudges, Helpers and Team Players: Oral Historical Accounts of Farm Work in Appalachian Kentucky.” Rural Sociology 61(2):20-226.

Sen, A. 2000. Repenser l'Inégalité. Paris: Seuil.

Sumner, J. and S. Llewelyn. 2011. “Organic Solutions?: Gender and Organic Farming in the Age of Industrial Agriculture.” Capitalism Nature Socialism 22:100-118.

Trauger, A. 2001. "Women Farmers in Minnesota and the Postproductivist Transition.” The Great Lakes Geographer 8(2): 53-66. . 2004. "'Because They Can Do the Work': Women Farmers and Sustainable Agriculture." Gender, Place \& Culture 11(2):289-307.

Umut Beşpiran, F. 2011. “Questioning Agency and Empowerment: Women's WorkRelated Strategies and Social Class in Urban Turkey.” Women's Studies International 
Forum 33(6):523-532.

2 U.S. Department of Agriculture (USDA). 2002. 2002 Census Report, Volume I. National Agricultural Statistics Service. Available at:

4 http://www.agcensus.usda.gov/Publications/2002/index.php. Accessed: 3/10/2014. . 2012. 2012 Census Preliminary Report. National Agricultural Statistics Service. Available at: .http://www.agcensus.usda.gov/Publications/2012/. Accessed: 3/9/2014.

7 Wells, B. 1998. "Creating a Public Space for Women in US Agriculture: Empowerment, Organization and Social Change.” Sociologia Ruralis 28:371-390.

9 Whatmore, S. 1991. Farming Women: Gender Work and Family Enterprise. London: Macmillan.

11 Williams, S, J. Seed, and A. Mwau. 1994. Oxfam Gender Training Manual. Oxford: Oxfam GB.

12 Yarwood, R. 2005. "Beyond the Rural: Images, Countryside Change and Geography." Geography 90(1):19-31.

14 